\title{
Surprizing Management
}

\author{
Wim Vandekerckhove ${ }^{1}$
}

Published online: 16 November 2020

(C) Springer Nature Switzerland AG 2020

When Russell first heard of this chap called Wittgenstein, he asked Moore what he thought of him. Moore said that he thought highly of Wittgenstein. Russell asked him why, to which Moore responded that from all those who attended his Cambridge seminars, Wittgenstein was the only one who looked surprised. Indeed, philosophy is often associated with surprise. Yet these are not the same. The ability to be surprised is a necessary condition to philosophize, but not a sufficient one. Let me put it this way, philosophy is a specific way of responding to surprise. Surprise without a response is perplexity, which means that basically unexpected reality knocks you down. Philosophy as a response to surprise takes the unexpected reality serious, in two ways. First, philosophy respects the surprising reality; perhaps even loves reality precisely because of its tendency to surprise. Second, philosophy is an attempt to move on, not by denial but rather by resolving the surprise through inquiry and plausibility.

That, is how I see philosophy's strength and hope. Thus, also that of philosophy of management. When I, as editor-in-chief, read manuscript submissions to this journal to decide whether or not to send them out to review, I look for what surprise drives the paper. Sometimes authors are explicit but other times I need to imagine. So there I am, wondering - if the paper is an inquiry to resolve a surprise - what was it that surprised the author(s)? That is my way of 'getting inside' a paper. Can I invite you along? We can take a tour of the papers in this issue the first fourth issue of a volume in this journal - looking for the surprise that triggered the philosophising about management.

Hughes (2020) was triggered by the public outrage about dramatic price increases by a number of pharmaceutical companies. The outrage indicates the urgency of the issue but is perhaps not surprising in itself; there is a vast literature on how government should shape and intervene in healthcare and medication markets. Yet Hughes (2020) doesn't 'rush in'. The surprise at the origin of the paper lies with the decision to, or even want of, such a huge profit from medication - even if you can, why would you? Hughes' starting question is: if you are legally free to raise prices, is it wise to do so?

The paper by Singh (2020) is the result of meta-surprise - I wish I could insert an emoticon here. Singh (2020) writes that 'if there is one question that has perplexed the best minds in every society, it is how to raise the individuals from their present state to a higher state of

Wim Vandekerckhove

w.vandekerckhove@greenwich.ac.uk

1 Centre for Research on Employment and Work (CREW), University of Greenwich, London, UK 
existence and perfection'. So what is this author surprised about? 's (2020) surprise is about what appears to be a universal 'quest for verticality', a quest that in itself stems from the surprise that we are here rather than there. The paper explores how this quest for verticality and self-perfection manifests itself in management scholarship and practice.

Van Straten (2020) asserts that strategic thinking can best be characterized as ongoing, resilient, and incomplete data. I understand van Straten (2020) as suggesting that it is good to be surprised, but that we need to be able to wade through the messiness. He writes that 'in strategic thinking, the firm and its environment constitute the object of thinking that is linked to the subject of thinking' (the individual strategist), who must 'at least try to imagine what it is like'. Be surprised but not perplexed, van Straten seems to say. The paper provides a framework to facilitate the 'self-directing learners' in thinking strategy.

Reveley (2020) draws on Object Oriented Ontology (OOO) - one of the 'new' realist ontologies to - as I imagine the author's motivation - allow surprise to be just that. Disasters and the coinciding destruction of 'things' (i.e. artefacts) is most often explained and managed using relational ontologies. Reveley (2020) acknowledges that a relational ontology is useful to respond to disasters because it provides insight into post-disaster organizing dilemmas. However, to better understand how disasters 'catch managers by surprise', we have to acknowledge the potential of artefacts to undergo substantial change. Reveley (2020) uses the case of a harbour as artefact and argues there is a tension between an artefact's design plan and its 'maximum plan'. Object-based surprise then, explains how artefacts have the potential to cause or worsen calamities.

Steiner (2020) draws on Levinas to bring empirical and theoretical scholarship on ethical leadership into conversation. The paper furthers this journal's scholarship on Levinas and management (see for example Bohl 2019; Faldetta 2019; Loumansky and Lewis 2013; Tajalli and Segal 2019; Trezise and Biesta 2009). It is my assertion here that Levinas' philosophy can be seen as one of endless surprise - in the sense that we are always responding to the Other's difference, without ever grasping that difference. Steiner (2020) employs Levinas' perspective that we cannot respond to the many others, and argues that such is the challenge of ethical leadership. Steiner's (2020) point is that a leader's demonstration of concern for the well-being of others in decision-making (i.e. acknowledge the unresolved surprise), is more important than the actual result of the decision.

Ghosh and Mukherjee (2020) provide a fascinating overview of Indian CSR and the various sources for its spiritual inspiration. Yet the empirical dip-toeing of the paper suggests that there is much work to be done in Indian management education (as elsewhere) to introduce the notion and possibility of surprise. Perhaps this paper can warn management educators not to be surprised if students do not see how deep cultural roots and wisdoms pertain to the management of everyday institutions and businesses, or fail to see the surprise in the everyday realities of these.

Finally, Rutherford (2020) applies memology to accounting standardization. He asks: can a new rule be a meme? It has been argued that laws and rules transmit memes, and indeed that legal doctrine itself transmits coded information. But what about financial statements, more precisely the rules through which such statements are produced? If these are standardized which is one of the things the accounting profession does - can we still speak of memetic evolution, or does standardization take the evolutionary dynamic out of it? In other words, does standardization preclude surprise in how rules change over time? Rutherford's (2020) conclusion is that the development of accounting is not disrupted by standardization. We can hence continue to be surprised. 
Imagining what surprise urges authors to write essays is not always easy. At times, it feels far-fetched. Even with very good papers. But I believe being explicit about surprise is what demarcates an excellent philosophical essay - any philosophy, and hence also philosophy of management.

\section{References}

Bohl, K.W. 2019. Leadership as phenomenon: Reassessing the philosophical ground of leadership studies. Philosophy of Management 18: 273-292. https://doi.org/10.1007/s40926-019-00116-x.

Faldetta, G. 2019. When relationships are broken: Restorative justice under a Levinasian approach. Philosophy of Management 18: 55-69. https://doi.org/10.1007/s40926-018-0094-1.

Ghosh, S., and S. Mukherjee. 2020. The relevance of spirituality and corporate social responsibility in management Education: Insights from Classical Indian Wisdom. Philosophy of Management. https://oi. org/10.1007/s40926-020-00141-1.

Hughes, R.C. 2020. Pricing medicine fairly. Philosophy of Management. https://doi.org/10.1007/s40926-02000135-z.

Loumansky, A., and D. Lewis. 2013. A Levinasian approach to whistleblowing. Philosophy of Management 12: 27-48. https://doi.org/10.5840/pom201312317.

Reveley, J. 2020. Artefacts, Surprise and Managing During Disaster: Object-Oriented Ontological and Assemblage-Theoretic Insights. Philosophy of Management. https://doi.org/10.1007/s40926-020-00138-w.

Rutherford, B.A. 2020. Are accounting standards memes? The Survival of Accounting Evolution in an Age of Regulation. Philosophy of Management. https://doi.org/10.1007/s40926-020-00142-0.

Singh, P.K. 2020. The quest for Verticality: An inquiry into the infinite nature of self-perfection. Philosophy of Management. https://doi.org/10.1007/s40926-020-00137-x.

Steiner, C. 2020. The influence of demonstrated concern on perceived ethical Leadership: A Levinasian Approach. Philosophy of Management. https://doi.org/10.1007/s40926-020-00139-9.

Tajalli, P., and S. Segal. 2019. Levinas, weber, and a hybrid framework for business ethics. Philosophy of Management 18: 71-88. https://doi.org/10.1007/s40926-018-0100-7.

Trezise, E., and G. Biesta. 2009. Can management ethics be taught ethically? A Levinasian Exploration. Philosophy of Management 8: 43-54. https://oi.org/10.5840/pom20098137.

van Straten, R. 2020. Six actionable canons for rationality in strategy practice. Philosophy of Management. https://doi.org/10.1007/s40926-020-00136-y.

Publisher's Note Springer Nature remains neutral with regard to jurisdictional claims in published maps and institutional affiliations.

Wim Vandekerckhove is Professor of Business Ethics and co-director of the Centre for Research on Employment and Work (CREW) at the University of Greenwich. He is editor-in-chief of Philosophy of Management. 